\title{
Statement
}

\section{당뇨병과 생체리듬}

\section{김진화}

\author{
조선대학교병원 내분비대사내과
}

\section{Diabetes and Circadian Rhythm}

\section{Jin Hwa Kim}

Department of Endocrinology and Metabolism, Chosun University Hospital, Gwangju, Korea

\begin{abstract}
All organisms on earth are governed by time-based biological rhythms. These biological rhythms are maintained by an endogenous circadian clock, which consists of the central clock in the suprachiasmatic nucleus of the hypothalamus and peripheral clocks. This clock sets its own program and builds networks for circadian timekeeping. The circadian clock regulates the cellular, physiological, and metabolic systems to synchronize biological cycles with environmental cycles. The flow of life in modern society is too complex and irregular to fit every endogenous circadian clock. Recently, the impact of circadian misalignment on health issues including diabetes, obesity, cardiovascular disease, and cancer, has attracted growing interest. Several studies suggest circadian rhythm of the association with glucose homeostasis. The understanding for circadian rhythm in glucose metabolism can present an opportunity for diabetes preventive strategies and improving glycemic control for people with diabetes.
\end{abstract}

Keywords: Circadian rhythm; Diabetes mellitus; Glucose intolerance

$\begin{array}{cl}\text { 서론 } & \text { 리나라 30세 이상 성인에서 당뇨병의 유병률은 } 14.4 \% \text { 에 이 } \\ & \text { 른다[1]. 건강하지 못한 식생활, 운동 부족, 그리고 비만 등 } \\ \text { 당뇨병 인구는 전 세계적으로 증가하고 있고, 2016년 우 } & \text { 이 당뇨병 발생의 주요 환경적 요인으로 거론되어 왔으나 }\end{array}$

Corresponding author: Jin Hwa Kim

Department of Endocrinology and Metabolism, Chosun University Hospital, 365 Pilmun-daero, Dong-gu, Gwangju 61453, Korea, E-mail: endocrine@chosun.ac.kr Received: May 1, 2020; Accepted: May 5, 2020

This is an Open Access article distributed under the terms of the Creative Commons Attribution Non-Commercial License (http://creativecommons.org/licenses/by$\mathrm{nc} / 4.0 /$ ) which permits unrestricted non-commercial use, distribution, and reproduction in any medium, provided the original work is properly cited.

Copyright (c) 2020 Korean Diabetes Association 
이것만으로 당뇨병의 가파른 증가세를 설명하기에는 역부 족이다.

현대사회는 고도화된 산업화 사회로 자연의 빛 이외에도 여러 인공적인 빛들이 존재하며, 그 안의 우리 일상은 “자연 의 시간"에 맞추어 하루하루 살아가기에는, 참 바쁘고 불규 칙하며, 또한 복잡하다. 지구 위의 모든 생물체는 “생체리 듬(circadian rhythm)"이라는 고유의 리듬을 갖는다. 모두 가 나만의 “일주기 시계(circadian clock)"를 갖고 있는 것 이다. 이 일주기 시스템은 생리학적 기능과 생물학적 프로 세스에 맞춘 매일 매일의 리듬을 위하여 진화되어 왔고, 생 체리듬은 지구 자전주기에 맞추어 24시간 주기로 조절된 다. 생체시계는 하루 중 여러 이벤트에 신체가 대처할 수 있 도록, 호르몬 분비, 심박동 수, 신장 혈류 속도, 수면주기, 그리고 체온 등을 조절한다[2]. 최근 이 생체리듬의 교란 (circadian disruption)이 호르몬, 생리학적 변화, 그리고 대 사 이상과 연관되며, 비만, 노화, 만성질환, 나아가 암 발생 의 위험도를 증가시킨다는 연구 결과들이 보고되며 그 역할 과 가능성에 관하여 주목하고 있다[3].

본 글에서는 당뇨병과 생체리듬에 관하여 포도당 대사와 생체리듬, 그리고 생체리듬의 교란과 제 2 형 당뇨병 발생 간 의 연관성에 관한 최근 연구 결과들을 바탕으로 정리하고자 한다.

\section{본론}

\section{1. 생체리듬과 생체리듬의 불일치(Circadian misalignment)}

생체리듬은 생체 내부 시계에 의해 조절된다. 시상하부 시교차상핵(suprachiasmatic nucleus)에 위치한 중앙시계 (central clock)와 더불어 여러 기관, 조직, 그리고 세포에 조직 특이적인 다양한 말초시계(peripheral clock)들이 존 재한다[4].

중앙시계는 다른 모든 시계들을 관장하며, 동시성 (synchronisation)을 맞춘다. 이 분자적 시계 구조는 CLOCK (circadian locomotor output cycles kaput),
BMAL1 (brain and muscle aryl hydrocarbon receptor nuclear translocator-like protein-1), PER 1, PER 2, PER3 (period circadian protein), CRY 1, CRY 2 (cryptochrome), ROR $\alpha$ (nuclear receptors retinoic acid receptor-like orphan receptor alpha), 그리고 REV-ERB $\alpha$ (reverse thyroid receptor $\alpha$ ) 등의 시간 유전자(core clock gene)를 포함하는 피드백 루프(transcription-translation negative feedback loop)로 구성된다. 시교차상핵에 빛 신 호가 망막시상하부로를 통해 전달되면, 시교차상핵은 신경, 온도, 그리고 호르몬 신호를 통해 뇌의 다른 영역 및 송과선 (pineal gland), 부신, 간, 췌장, 근육, 지방조직, 그리고 위 장관 등 여러 말초기관에 시간 신호를 전달한다. 시교차상 핵의 중앙시계는 또한 말초기관 내에 위치한 각각의 시계들 의 동시성을 관장하며 시계 조절 유전자에 영향을 미침으로 서 각 기관들의 기능을 조정한다[5].

말초기관 내의 시계, 특히 간과 같이 대사와 관련된 기관 들의 시계는 시교차상핵의 중앙시계로부터의 신경내분비 신호 이외에도 운동, 음식섭취, 그리고 시차변화와 같이 빛 이 아닌 자극에 의해서도 영향을 받는다[6].

산업화 사회를 살아가고 있는 현대인은 중앙시계가 인지 한 자연의 낮과 밤(빛과 어둠) 주기와, 환경적 주기(자연적 으로는 밤이지만 인공적 빛을 통해 낮과 같은 환경), 그리고 행동 주기(음식섭취 시간, 활동 시간, 일하는 시간, 휴식 시 간, 수면주기)들 간에 불일치(circadian misalignment)를 흔히 경험한다. 중앙시계가 인지하는 밤, 어둠(휴식, 수면, 음식섭취 중단)의 주기에 인공의 빛을 통해, 그 속에서 활동 하고 일하며 음식을 섭취한다. 교대 근무와 해외여행(시차 변화) 또한 이러한 주기의 불규칙성을 초래할 수 있다. 내부 생체주기에 어긋나는 리듬의 불일치는 대사적 이상을 초래 하며 건강에 영향을 미칠 수 있다[3].

\section{2. 생체리듬과 포도당 대사}

혈당과 인슐린 분비는 일주기 리듬을 갖고 포도당 항상성 은 시간에 의해 조절된다. 1960년대 포도당 내성과 인슐린 
감수성이 아침에 비하여 저녁에 더 낮아진다는 결과가 보고 되었고[7], 이러한 패턴은 경구당부하 검사를 통해서도 확 인되었다. 인슐린 감수성과 베타세포 기능이 저녁에 감소 하며 포도당 내성이 감소되었다[8]. 제2형 당뇨병 환자에서 고혈당 클램프를 통해 인슐린 민감도의 하루 중 리듬을 보 았을 때, 밤에 인슐린 민감도가 감소되고 간의 포도당 생산 이 증가되었다[9]. 제2형 당뇨병 환자의 경우 정상체중의 당뇨병이 없는 사람들의 안정적 혈당과는 반대로 밤부터 아 침까지 수면시간 동안 혈당 수치의 증가를 보였고[10], 이 는 공복혈당 상승과 연관된다.

하루의 리듬은 내부의 리듬과 환경적, 그리고 행동 리듬 에 따라 형성된다. 포도당 대사의 일 중 내부리듬을 정확 히 파악하기 위해서는 수면, 음식섭취, 활동 시간 등 환경 적, 그리고 행동적 영향의 조정이 필요하여 연구에 어려움 이 있다. 외부의 영향을 배제한 실험적 환경에서 시행된 연 구에서 내부 생체리듬은 아침과 저녁의 포도당 내성에 차이 를 보였다. 생체적으로 저녁시간의 식후 혈당이 아침시간에 비하여 $17 \%$ 높았으며, 식사 후 초기 인슐린 분비는 저녁시 간이 아침시간에 비하여 $27 \%$ 낮았다[11]. 포도당 항상성에 대한 이러한 일주기의 영향은 생체적 아침시간에 췌장의 베 타세포 반응이 높다는 결과에 일부 기인할 수 있다[12]. 포 도당 대사에 대한 내부 생체리듬의 정확한 영향을 파악하기 위해서는 외부 영향을 최대한 배제한 더 나은 연구 프로토 콜이 요구된다.

제 2 형 당뇨병 환자와 당뇨병이 없는 사람들 사이의 포도 당 대사의 일 중 리듬의 차이가 생체리듬과 연관될 수 있 다는 최근 연구 결과가 있다. 제 2 형 당뇨병 환자의 시교차 상핵 내 중앙 시계의 영향과 관련하여, 특히, 시교차상핵 내 arginine vasopression immunoreactive (AVP-ir) 뉴 런, vasoactive intestinal polypeptide immunoreactive (VIP-ir) 뉴런, 그리고 glical fibrillary acidic protein immunoreactive (GFAP-ir) 세포수가 대조군에 비하여 제 2형 당뇨병 환자에서 감소되었다[13]. BMAL1을 제거한 쥐에서 포도당 불내성 및 인슐린 분비능 저하가 관찰되었다 〔14].
포도당 항상성과 관련하여 간세포 내 생체시계 또한 포도 당 신생성, 포도당 이송, 그리고 지방 대사에 기여한다. 인 슐린 분비속도는 일주기 리듬을 보이는데, 췌장 내 분자적 생체시계가 인슐린 분비의 시간 및 변동폭과 연관된다. 췌 장의 생체시계는 인슐린 분비, 베타세포의 분화 및 성장, 산 화 스트레스에 대한 방어, 그리고 대사와 연관된 유전자를 조정한다[15]. 베타세포 내 생체시계를 파괴시킨 쥐는 포도 당 불내성 및 포도당 자극에 의한 인슐린 분비능에 이상을 보였다[16].

\section{3. 생체리듬의 교란과 당뇨병}

동물모델에서 시간 유전자의 기능 이상(CLOCK, CRY 1, CRY 2, BMAL1)은 고혈당, 인슐린 민감성 저하, 그리고 인슐린 분비 저하와 연관되었다[17].

장 호르몬(glucagon, insulin, gastric inhibitory peptide, glucagon-like peptide-1, amylin, peptide YY, ghrelin)은 포도당 항상성 유지에 중요한 역할을 담당하는데 생체리듬 주기의 교란은 이러한 호르몬의 활성화 패턴에 변형을 초 래하여 당뇨병 발생에 영향을 미칠 수 있다. 장내 미생물군 (gut microbiota) 또한 내부 생체리듬의 관장 하에 있으며 생체리듬의 교란 및 불균형은 미생물군의 구조 및 대사적 활성화에 영향을 미친다. 이러한 이상은 인슐린 저항성뿐 아니라 비만, 지방세포 및 면역, 염증 반응에 이상을 초래하 고 음식으로부터 에너지 흡수에도 영향을 미쳐 포도당 항상 성 유지를 어렵게 함으로서 당뇨병 발생과 연관될 수 있다 [18].

쥐의 췌도 세포를 빛에 지속적으로 노출시킨 결과 생체시 계 기능의 교란과 포도당 자극에 의한 인슐린 분비 감소가 관찰되었다. 또한, 췌도의 생체시계가 췌도 세포의 성장과 포도당 수치를 감지하여 인슐린 분비를 조정하는 유전자 발 현을 조정한다는 실험 결과가 보고되었다[19].

생체리듬의 교란, 내부 일주기 리듬과 환경적/행동 주기 간의 불일치가 제 2 형 당뇨병 발생 위험도를 증가시킨다는 역학적 연구 결과들이 있다. 교대 근무는 아침과 낮, 활동과 
수면 패턴의 변화로 인하여 생체리듬의 불일치를 초래할 수 있고, $10 \sim 40 \%$ 의 당뇨병 위험도 증가와 연관되었다[20]. 메타분석에서 교대 근무자의 경우 비 교대 근무자에 비하여 당뇨병 발생의 위험도가 $9 \%$ 증가하였다. 교대 근무자는 밤 에만 지속적으로 일하는 근무자에 비하여 당뇨병의 발생 위 험도가 더 높았다[21]. 교대 근무자에서 시행된 또 다른 연 구에서, 밤 근무자가 낮 근무자에 비하여 식후혈당, 인슐린, 그리고 중성지방 수치가 높았다[22].

생체리듬의 교란에 대한 시험적 연구에서 참여자들은 생 체주기에 일치되어 생활하는 시기에 비하여, 생체리듬과 어 긋나는 시기에 식후혈당이 $6 \%$ 상승하였고 후기 인슐린 반 응이 $10 \%$ 상승되었다[23].

생활패턴과 관련하여 늦게 자고 늦게 일어나는(밤에 활 동, 아침에 수면) 사람은 일찍 자고 일찍 일어나는(밤에 수 면, 아침에 활동) 사람에 비하여 당뇨병의 위험도가 수면시 간과 무관하게 2 2.5배 상승되었다[24]. 밤에 늦게까지 활 동하는 경우 늦은 시간에 음식섭취를 할 수 있는데, 생체리 듬의 교란과 함께 이러한 생활습관과 관련된 요인 또한 당 뇨병 발생 위험에 영향을 미칠 수 있다. 최근 한 무작위 대 조군 연구에서 늦은 식사 시간은 멜라토닌 증가와 함께 포 도당 불내성의 결과를 보여주었다[25]. 늦은 시간의 음식섭 취는 “수면시간”으로 인식하고 있는 내부 생체주기에 교란 을 생성하여 여러 진화단계를 거쳐 형성된, 그리고 유기적 으로 소통하고 있는 신체 기관의 오케스트라에 불협화음을 초래할 수 있다.

\section{결론}

제2형 당뇨병 인구의 증가가 예상되는 현 시점에서, 예방 및 환자 개개인의 특성에 따른 개별화된 관리는 중요하며 이를 위한 노력은 지속되어야 한다. 당뇨병과 생체리듬, 그 리고 그 교란이 미치는 영향에 대한 기전을 파악하고 적용 하기 위한 여러 분야의 전문적 협업이 요구되는 시점이다.

현대사회를 살아가는 우리의 일상은 참 복잡하고 불규칙 하지만 더 나은 건강한 미래를 위하여, 오늘은 “나의 시계"
에 귀 기울이고 그 리듬에 맞추어 단순하고 규칙적으로 살 아갈 수 있기를 기대한다.

\section{REFERENCES}

1. Korean Diabetes Association. Diabetes fact sheet in Korea 2018. Seoul: Korean Diabetes Association; 2018.

2. Bass J, Takahashi JS. Circadian integration of metabolism and energetics. Science 2010;330:1349-54.

3. Roenneberg T, Merrow M. The circadian clock and human health. Curr Biol 2016;26:R432-43.

4. Rosenwasser AM, Turek FW. Neurobiology of circadian rhythm regulation. Sleep Med Clin 2015;10:403-12.

5. Sollars PJ, Pickard GE. The neurobiology of circadian rhythms. Psychiatr Clin North Am 2015;38:645-65.

6. Honma S. The mammalian circadian system: a hierarchical multi-oscillator structure for generating circadian rhythm. J Physiol Sci 2018;68:207-19.

7. Jarrett RJ, Keen H. Diurnal variation of oral glucose tolerance: a possible pointer to the evolution of diabetes mellitus. Br Med J 1969;2:341-4.

8. Van Cauter E, Polonsky KS, Scheen AJ. Roles of circadian rhythmicity and sleep in human glucose regulation. Endocr Rev 1997; 18:716-38.

9. Boden G, Chen X, Urbain JL. Evidence for a circadian rhythm of insulin sensitivity in patients with NIDDM caused by cyclic changes in hepatic glucose production. Diabetes 1996;45:1044-50.

10. Shapiro ET, Polonsky KS, Copinschi G, Bosson D, Tillil H, Blackman J, Lewis G, Van Cauter E. Nocturnal elevation of glucose levels during fasting in noninsulin-dependent diabetes. J Clin Endocrinol Metab 1991;72:444-54.

11. Morris CJ, Yang JN, Garcia JI, Myers S, Bozzi I, Wang W, Buxton OM, Shea SA, Scheer FA. Endogenous circadian system and circadian misalignment impact glucose 
tolerance via separate mechanisms in humans. Proc Natl Acad Sci U S A 2015;112:E2225-34.

12. Qian J, Dalla Man C, Morris CJ, Cobelli C, Scheer FAJL. Differential effects of the circadian system and circadian misalignment on insulin sensitivity and insulin secretion in humans. Diabetes Obes Metab 2018;20:2481-5.

13. Hogenboom R, Kalsbeek MJ, Korpel NL, de Goede P, Koenen M, Buijs RM, Romijn JA, Swaab DF, Kalsbeek A, Yi CX. Loss of arginine vasopressin- and vasoactive intestinal polypeptide-containing neurons and glial cells in the suprachiasmatic nucleus of individuals with type 2 diabetes. Diabetologia 2019;62:2088-93.

14. Lamia KA, Storch KF, Weitz CJ. Physiological significance of a peripheral tissue circadian clock. Proc Natl Acad Sci U S A 2008; 105:15172-7.

15. Lee J, Liu R, de Jesus D, Kim BS, Ma K, Moulik M, Yechoor V. Circadian control of $\beta$-cell function and stress responses. Diabetes Obes Metab 2015;17 Suppl 1:123-33.

16. Marcheva B, Ramsey KM, Buhr ED, Kobayashi Y, Su H, Ko CH, Ivanova G, Omura C, Mo S, Vitaterna MH, Lopez JP, Philipson LH, Bradfield CA, Crosby SD, JeBailey L, Wang X, Takahashi JS, Bass J. Disruption of the clock components CLOCK and BMAL1 leads to hypoinsulinaemia and diabetes. Nature 2010;466:627-31.

17. Qian J, Scheer FAJL. Circadian system and glucose metabolism: implications for physiology and disease. Trends Endocrinol Metab 2016;27:282-93.

18. Parkar SG, Kalsbeek A, Cheeseman JF. Potential role for the gut microbiota in modulating host circadian rhythms and metabolic health. Microorganisms 2019;7:41.

19. Stenvers DJ, Scheer FAJL, Schrauwen P, la Fleur SE, Kalsbeek A. Circadian clocks and insulin resistance. Nat Rev Endocrinol 2019;15:75-89.

20. Vetter C, Dashti HS, Lane JM, Anderson SG, Schernhammer ES, Rutter MK, Saxena R, Scheer FAJL. Night shift work, genetic risk, and type 2 diabetes in the UK biobank. Diabetes Care 2018;41:762-9.

21. Gan Y, Yang C, Tong X, Sun H, Cong Y, Yin X, Li L, Cao S, Dong X, Gong Y, Shi O, Deng J, Bi H, Lu Z. Shift work and diabetes mellitus: a meta-analysis of observational studies. Occup Environ Med 2015;72:72-8.

22. Kiranmala K, Aslam M, Mishra BK, Jhamb R, Madhu SV. Association of postprandial triglyceride responses with insulin resistance among rotational night shift healthcare workers. Exp Physiol 2019;104:819-25.

23. Morris CJ, Purvis TE, Mistretta J, Scheer FA. Effects of the internal circadian system and circadian misalignment on glucose tolerance in chronic shift workers. J Clin Endocrinol Metab 2016;101:1066-74.

24. Finn L, Young E, Mignot E, Young T, Peppard P. Associations of eveningness chronotype with adverse metabolic indications in the Wisconsin Sleep Cohort. Sleep 2013;36:188.

25. Garaulet M, Qian J, Florez JC, Arendt J, Saxena R, Scheer FAJL. Melatonin effects on glucose metabolism: time to unlock the controversy. Trends Endocrinol Metab 2020;31:192-204. 